\title{
Dependence of Sorghum bicolor antioxidant activity on harvest time
}

\author{
Seung-Ho Jeon ${ }^{\mathrm{a}}$, Il-Suk Kim ${ }^{\mathrm{b}}$, Soo-Kwon Park ${ }^{\mathrm{c}}$, Ki-Youl Jung ${ }^{\mathrm{c}}$, Sam Woong Kim ${ }^{\mathrm{b}}$, Young-Son Cho ${ }^{\mathrm{a}, *}$ \\ a Department of Agronomy \& Medicinal Plant Resources, \\ Gyeongnam National University of Science and Technology, Jinju 52725, South Korea \\ b Swine Science and Technology Centre, Gyeongnam National University of Science \& Technology, \\ Jinju 52725, South Korea \\ c National Institute of Crop Science, Rural Development Administration, Wanju 55365, South Korea
}

*Corresponding author, e-mail: yscho@gntech.ac.kr

Received 20 Dec 2016

Accepted 23 Jun 2017

\begin{abstract}
This study was done to examine the correlation between differential contents of antioxidants and their antioxidative activities in the seeds obtained from two sorghum cultivars (Nampungchal and Hwanggeumchal) according to harvest time post heading, and to understand the properties of the harvested seeds. The seeds were harvested every 5 days from 25-55 days post heading. Length, width, thickness, and morphological properties of the obtained seeds were increased in proportion to the harvest time. The weights per thousand grains, crude fat, and redness $\left(a^{*}\right)$ clearly changed depending on the harvest time. The grain weight and fat content showed the highest value at harvest time days 45 (HT 45). The seed coat lightness $\left(L^{*}\right)$, crude protein, total polyphenol, flavonoid, and tannin in both cultivars were inversely proportional to the harvest time. In addition, ABTS and DPPH radical scavenging activities were also reduced in inverse proportion to the elapsed harvest time. Antioxidants including polyphenol, flavonoid, and tannin showed positive correlations with the antioxidative activities such as ABTS and DPPH activities, but antioxidants and their activities had no significant correlations between cultivars. We therefore propose that sorghum harvest is performed earlier to improve its antioxidative function.
\end{abstract}

KEYWORDS: polyphenol, seed morphology

\section{INTRODUCTION}

The improvement of life quality and diffusion of a culture of well-being according to economic growth have promoted public interest in functional cereals. Countries where rice is the main food demand functional boiled rice and mixed application of other grains with rice for health promotion. Functional cereals have so far been recognized as crops of a low yield using a small cultivation area, but are preferred by consumers. Since 2007, demand and import of functional cereals in South Korea has been rapidly risen to 69000 and 50000 t, respectively ${ }^{1}$. In addition, they are applied in various ways such as new industrial materials, foods, pharmaceuticals, and natural dyes, as well as are employed as excellent crops for conservation of landscape and environment.

Among functional cereals, Sorghum bicolor is a representative $\mathrm{C}_{4}$ crop originated from Africa, which is cultivated mainly in the subtropical and semi-arid regions including India to maintain rainfall below $400 \mathrm{~mm}$ per year. S. bicolor requires $50 \%$ less water than corn, as it has a high absorption ability and low nutrient demand ${ }^{2-4}$. In addition, it contains a number of bioactive components such as dietary fibre and phenolic compounds, including flavonoid, tannin, and phenolic acids ${ }^{5-7}$.

Phenolic compounds included in sorghum exhibit a strong anti-mutagenic activity and sorghum extracts show a strong antioxidant activity ${ }^{8-10}$. Sorghum functionality has been examined in previous studies such as assays of antioxidant and antibiotic activities after methanol extraction followed by sequential solvent fractionation ${ }^{11}$, measurement of anthocyanin antioxidant activity ${ }^{12}$, and study of phenolic acid, flavonoid, and tannin ${ }^{13-15}$.

Although sorghum has been actively studied for antioxidant components and physiological function, there is no result for changes of major chemical and antioxidant components from the harvested seeds according to cultivation time. Hence, in this study, we examined specific properties of sorghum including measurements of representative antioxidant components and their activities depending on harvest time post heading. 


\section{MATERIALS AND METHODS}

\section{Sorghum seed harvest and treatment}

Sorghum cultivars employed in this study (cv. Nampungchal and Hwanfgeumchal) were cultivated in an experimental field $\left(35^{\circ} 05^{\prime} 16^{\prime \prime} \mathrm{N}, 127^{\circ} 56^{\prime} 34^{\prime \prime} \mathrm{E}\right)$ in Sacheon, Gyeongnam, South Korea in 2014. Sorghum was harvested 7 times at intervals of 5 days from 25-55 days post heading (HT 25, 30, $35,40,45,50,55)$. The harvested sorghum seeds were well-dried to a moisture content of approximately $13 \%$, and then applied as samples after removing the hull surrounding the grain.

\section{Morphological properties of seeds}

Morphological property of the seeds was examined by 4 repeated experiments to 100 normal grains per individual assay from each harvested sorghum seed. Morphological assay of the seeds was examined for length, width, and thickness. The seed coat colour values such as lightness $\left(L^{*}\right)$, redness $\left(a^{*}\right)$, and yellowness $\left(b^{*}\right)$ were determined by spectrophotometry (Minolta spectrophotometer, cm-3500d, Japan).

\section{Analyses of chemical composition, total polyphenol, flavonoid, and tannin}

The samples were crushed for $10 \mathrm{~min}$ at $4600 \mathrm{rpm}$ by a pin mill pulverization (DK201, Sejung Tech, Daegu, Korea) and then a fraction was applied for analysis of chemical compositions according to AOAC method ${ }^{16}$.

Total polyphenol content was assayed by FolinCiocalteu phenol reagent ${ }^{17}$. One millilitre of $2 \%$ $\mathrm{Na}_{2} \mathrm{CO}_{3}$ solution was mixed with $50 \mu \mathrm{l}$ of sample; the mixed solution was incubated for $3 \mathrm{~min}$, and then $50 \mu \mathrm{l}$ of $50 \%$ Folin-Ciocalteu reagent (Sigma-Aldrich, St. Louis, MO, USA) was added into the mixed solution. After reacting for $30 \mathrm{~min}$ at room temperature, the absorbance at $750 \mathrm{~nm}$ of the treated solution was measured (Multiscan GO, Thermo Scientific Co. Ltd., USA). The regression line is represented by $y=0.003 x\left(R^{2}=0.989\right)$ in $\mathrm{mg}$ of gallic acid (dry basis) per $\mathrm{g}$ of sample.

Total flavonoid content was determined according to the method of Dewanto et $\mathrm{al}^{17}$. The reaction solution was prepared by $1 \mathrm{ml}$ of distilled water, $75 \mu \mathrm{l}$ of $5 \% \mathrm{NaNO}_{2}$ and $250 \mu \mathrm{l}$ of sample, and then incubated for $5 \mathrm{~min}$ at room temperature. The reacted solution was additionally mixed with $500 \mu \mathrm{l}$ of $1 \mathrm{~N} \mathrm{NaOH}$, and then left to react for $11 \mathrm{~min}$ at room temperature. The absorbance at $510 \mathrm{~nm}$ of the treated solution was measured (Multiscan GO, Thermo Scientific Co. Ltd., USA). The regression line is represented by $y=0.005 x\left(R^{2}=0.998\right)$ in $\mathrm{mg}$ of catechin (dry basis) per $\mathrm{g}$ of sample.

Total tannin was measured according to the method of Duval and Shetty ${ }^{18}$. Reaction solution was prepared with $1 \mathrm{ml}$ of $95 \%$ ethanol, $1 \mathrm{ml}$ of distilled water and $1 \mathrm{ml}$ of sample solution. After mixing, $1 \mathrm{ml}$ of $5 \% \mathrm{Na}_{2} \mathrm{CO}_{3}$ solution and $0.5 \mathrm{ml}$ of $1 \mathrm{~N}$ Folin-Ciocalteu reagent (Sigma-Aldrich) were added into the mixed solution, and the reaction was allowed to develop colour for $60 \mathrm{~min}$ at room temperature. The absorbance at $725 \mathrm{~nm}$ of the treated solution was measured (Multiscan GO, Thermo Scientific Co. Ltd., USA). The calibration line ( $y=$ $\left.0.0097 x, R^{2}=0.9769\right)$ was prepared in $\mathrm{ml}$ of tannic acid (dry basis) per $g$ of the sample.

\section{Assays for ABTS and DPPH radical scavenging activities}

The antioxidative activity of the sample was measured by ABTS (2,2' -azino-bis-3-ethylbenzo-thiazoline-6-sulphonic acid, Sigma-Aldrich) and DPPH (1,1-diphenyl-2-picrylhydrazyl, Sigma-Aldrich) radical scavenging activities ${ }^{19,20}$. To measure the ABTS radical scavenging activity, $50 \mu \mathrm{l}$ of sample was mixed with $1 \mathrm{ml}$ of a diluted ABTS solution, let it react for $30 \mathrm{~min}$ at room temperature, and then the absorbance was measured at $735 \mathrm{~nm}$ wavelength (Thermo Scientific Co. Ltd., USA). ABTS scavenging activity was expressed in $\mathrm{mg}$ of TE (Trolox equivalent antioxidant capacity) per $\mathrm{g}$.

To measure the DPPH radical scavenging activity, $0.2 \mathrm{ml}$ of sample was mixed with $0.8 \mathrm{ml}$ of $0.2 \mathrm{mM}$ DPPH solution dissolved in $99.9 \%$ methanol, let react for $30 \mathrm{~min}$, and the absorbance at $520 \mathrm{~nm}$ was measured (Thermo Scientific Co. Ltd., USA). DPPH scavenging activity was expressed in $\mathrm{mg}$ of $\mathrm{TE}$ per $\mathrm{g}$.

\section{Statistical analysis}

The average value of collected data was compared, with a significance level of 5\%, through Duncan's multiple rage test (DMRT) by PROC ANOVA procedures of SAS 9.2 (Cary, NC).

\section{RESULTS AND DISCUSSION}

\section{Morphological properties of sorghum seeds}

To analyse the seed morphological properties at each harvest time, the harvested sorghum seeds were examined for length, width, thickness, and weight per thousand grains (Fig. 1). As a result of seed length, Nampungchal seed (NPC; $3.58 \mathrm{~mm}$ ) was $0.52 \mathrm{~mm}$ longer than that of Hwanggeumchal 

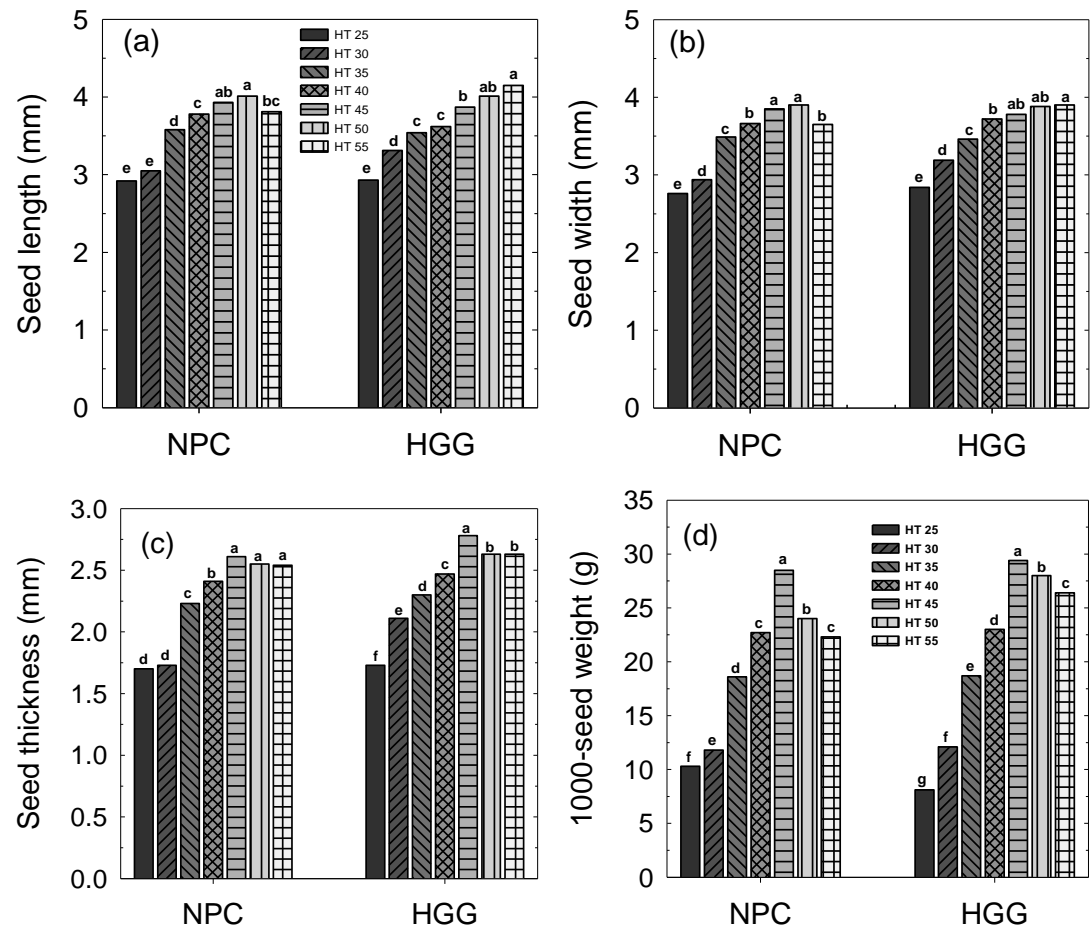

Fig. 1 Morphological properties according to each harvest time of sorghum; (a) seed length, (b) seed width, (c) seed thickness, (d) thousand-grain weight. The different superscripts in bar graphs indicate significant differences at $p<0.05$ by Duncan's multiple range test.

seed (HGC; $3.06 \mathrm{~mm}$ ). The seed length showed a clear difference depending on the harvest time. The longest lengths of NPC and HGC at HT 50 and HT 55 were $4.01 \mathrm{~mm}$ and $4.15 \mathrm{~mm}$, respectively, whereas shortest lengths of both seeds occurred at the earliest harvest time of HT 25 as 2.92 and $2.93 \mathrm{~mm}$, respectively. NPC and HGC showed the longest width of $3.90 \mathrm{~mm}$ at HT 50 and HT 55, respectively. NPC and HGC showed the maximum thickness of $2.54 \mathrm{~mm}$ and $2.78 \mathrm{~mm}$ at HT 45 .

Length and width of the college glutinous corn increase according to harvest time ${ }^{21}$. Hence it is assumed that sorghum has differential growth properties and harvest time with college glutinous corn. Weight per thousand grains showed a clear difference according to harvest time. When the seeds of NPC and HGC presented the longest width and the maximum thickness, they showed the maximum weights of $28.5 \mathrm{~g}$ and $28.4 \mathrm{~g}$, respectively, at HT 45 . Both cultivars showed the minimum weights at the earliest harvest time of HT 25. Hence, according to width, thickness, and weight of the seeds, we suggest that sorghum seed is optimal at HT 45.

Lightness $\left(L^{*}\right)$ and yellowness $\left(b^{*}\right)$ among seed coat colours was inversely proportional to the har- vest time, whereas redness $\left(a^{*}\right)$ followed an opposite trend (Table 1). Interestingly however, the $b^{*}$ value of HGC increased depending on the harvest time. It is assumed that the differential results between cultivars are greatly influenced by genetic differences. On the other hand, as shown in other crops $^{22,23}$, the value of $a^{*}$, highly related to the content of anthocyanin in sorghum, increases at later harvest time. Although more detailed research remains to be done in the future, we suggest that the harvest time is considered for utilization of anthocyanins.

\section{Chemical compositions}

As shown in Table 2, chemical compositions including protein, fat, and ash showed similar values to those of Korean sorghum ${ }^{24}$. The content of crude protein in both cultivars decreased as the cultivation period elapsed. The content of crude protein (8.58$10 \%)$ in NPC was slightly lower than that of HGC (9.09-14\%). Crude fat in NPC showed the lowest amount (3\%) at an earliest harvest time (HT 25), where it showed the largest amount of $5 \%$. Crude fat in HGC exhibited also the highest amount (5\%) at HT 45. In contrast to the content of crude 
Table 1 Changes of seed coat colour according to harvest time of sorghum.

\begin{tabular}{|c|c|c|c|c|c|c|}
\hline \multirow{2}{*}{$\begin{array}{c}\mathrm{HT} \\
\text { (day) }\end{array}$} & \multicolumn{3}{|c|}{ NPC } & \multicolumn{3}{|c|}{ HGC } \\
\hline & $L^{*}$ & $a^{*}$ & $b^{*}$ & $L^{*}$ & $a^{*}$ & $b^{*}$ \\
\hline 25 & $85.6 \pm 2.7^{\mathrm{a}}$ & $3.0 \pm 1.5^{\mathrm{d}}$ & $58.9 \pm 2.1^{\mathrm{a}}$ & $86.0 \pm 2.1^{\mathrm{a}}$ & $3.6 \pm 1.2^{\mathrm{e}}$ & $47.1 \pm 2.3^{b}$ \\
\hline 30 & $84.3 \pm 4.2^{\mathrm{a}}$ & $3.0 \pm 1.7^{\mathrm{d}}$ & $59.0 \pm 4.2^{\mathrm{a}}$ & $84.7 \pm 2.5^{\mathrm{ab}}$ & $4.0 \pm 1.7^{\mathrm{e}}$ & $47.0 \pm 8.7^{\mathrm{b}}$ \\
\hline 35 & $72.3 \pm 5.5^{\mathrm{b}}$ & $17.7 \pm 2.9^{c}$ & $56.3 \pm 2.9^{\mathrm{ab}}$ & $83.7 \pm 3.5^{\mathrm{ab}}$ & $7.3 \pm 3.1^{\mathrm{d}}$ & $48.3 \pm 7.6^{b}$ \\
\hline 40 & $71.3 \pm 7.1^{\mathrm{b}}$ & $20.0 \pm 7.5^{b c}$ & $55.0 \pm 3.6^{\mathrm{ab}}$ & $74.3 \pm 5.0^{\mathrm{b}}$ & $15.0 \pm 5.2^{\mathrm{c}}$ & $50.7 \pm 8.1^{\mathrm{b}}$ \\
\hline 45 & $70.7 \pm 9.1^{b}$ & $17.7 \pm 8.0^{c}$ & $53.7 \pm 3.8^{b}$ & $58.3 \pm 2.5^{c}$ & $30.3 \pm 3.2^{\mathrm{b}}$ & $53.0 \pm 2.0^{\mathrm{ab}}$ \\
\hline 50 & $55.3 \pm 3.2^{\mathrm{c}}$ & $27.7 \pm 3.5^{\mathrm{b}}$ & $50.7 \pm 4.2^{\mathrm{b}}$ & $55.3 \pm 9.0^{c}$ & $37.0 \pm 6.1^{\mathrm{ab}}$ & $56.7 \pm 4.0^{\mathrm{a}}$ \\
\hline 55 & $51.3 \pm 1.1^{\mathrm{c}}$ & $40.0 \pm 3.6^{\mathrm{a}}$ & $46.7 \pm 2.1^{c}$ & $41.3 \pm 2.5^{d}$ & $39.3 \pm 0.6^{\mathrm{a}}$ & $52.3 \pm 2.3^{b}$ \\
\hline
\end{tabular}

$L^{*}$ : lightness; $a^{*}$ : redness ( + red, - green); $b^{*}$ : yellowness (+ yellow, - blue). Values are mean \pm SD. Different superscript letters in the same column indicate significant difference based on Duncan's multiple range tests $(p<$ 0.05).

Table 2 Chemical compositions according to harvest time of sorghum seed.

\begin{tabular}{lcccccccc}
\hline Cultivar & $\begin{array}{c}\text { HT } \\
\text { (day) }\end{array}$ & $\begin{array}{c}\text { Crude protein } \\
(\%)\end{array}$ & $\begin{array}{c}\text { Crude fat } \\
(\%)\end{array}$ & $\begin{array}{c}\text { Crude ash } \\
(\%)\end{array}$ & $\begin{array}{c}\mathrm{K} \\
(\%)\end{array}$ & $\begin{array}{c}\mathrm{Ca} \\
(\%)\end{array}$ & $\begin{array}{c}\mathrm{Mg} \\
(\%)\end{array}$ & $\begin{array}{c}\mathrm{Na} \\
(\%)\end{array}$ \\
\hline NPC & 25 & 10.35 & 3.22 & 1.20 & 0.632 & 0.039 & 0.280 & 0.008 \\
& 30 & 10.03 & 3.69 & 1.20 & 0.674 & 0.043 & 0.333 & 0.004 \\
& 35 & 9.72 & 3.80 & 1.30 & 0.555 & 0.023 & 0.231 & 0.004 \\
& 40 & 9.65 & 4.09 & 1.33 & 0.545 & 0.024 & 0.289 & 0.005 \\
& 45 & 9.28 & 4.59 & 1.35 & 0.501 & 0.021 & 0.270 & 0.007 \\
& 50 & 9.28 & 4.26 & 1.41 & 0.462 & 0.023 & 0.246 & 0.007 \\
HGC & 55 & 4.58 & 4.19 & 1.53 & 0.456 & 0.025 & 0.238 & 0.007 \\
& 25 & 13.82 & 2.25 & 1.10 & 0.704 & 0.080 & 0.376 & 0.006 \\
& 30 & 10.47 & 3.19 & 1.11 & 0.630 & 0.045 & 0.310 & 0.005 \\
& 35 & 10.10 & 3.85 & 1.11 & 0.560 & 0.032 & 0.279 & 0.006 \\
& 40 & 9.53 & 3.98 & 1.12 & 0.530 & 0.025 & 0.267 & 0.006 \\
& 45 & 9.28 & 4.76 & 1.13 & 0.520 & 0.021 & 0.214 & 0.005 \\
& 50 & 9.09 & 4.44 & 1.13 & 0.559 & 0.021 & 0.332 & 0.007 \\
& 55 & 9.09 & 4.33 & 1.18 & 0.502 & 0.020 & 0.269 & 0.005 \\
\hline
\end{tabular}

protein as described above, the content of ash in both cultivars increased as the harvest time elapsed. The contents of ash in NPC and HGC increased from $1.20-2 \%$ and from $1.10-1 \%$, respectively.

The contents of magnesium and sodium in both cultivars changed from $0.214-0.376 \%$ and from 0.004-0.008\%, respectively, both of which did not show any apparent difference with harvest time. However, the content of potassium in NPC and HGC showed the highest values of $0.674 \%$ and $0.704 \%$ at an earlier harvest time (HT 30 and HT 25 , respectively), which decreased depending on the elapsed harvest time. Hence the content of potassium in NPC and HGC at HT 55 showed the lowest values of $0.456 \%$ and $0.502 \%$, respectively. After the content of calcium decreased from HT 25 to HT 35, it remained at a constant level.

Taken together, crude protein and ash contents in both cultivars increased according to the elapsed harvest time, whereas fat, potassium, and calcium contents showed the opposite trend. Hence we suggest that sorghum seed is harvested at an early time to obtain the maximal nutrient composition.

\section{Antioxidant components}

Phenolic hydroxyl radicals have been known to play physiological roles such as antioxidants, anticancer, and antibiotics through combination with a macromolecule including proteins ${ }^{25}$. Polyphenolic compounds among antioxidant substances contained in crops exhibit excellent antioxidant properties owing to the phenolic ring that stabilizes free radicals ${ }^{26,27}$. Both sorghum cultivars maintained higher total polyphenolic content at an earlier harvest time (Fig. 2a). NPC showed differences in total polyphenol content between the earliest harvest time $(34.8 \mathrm{mg} / \mathrm{g}$ at HT 25) and the latest harvest time (15.4 mg/g at HT 55), but relatively 

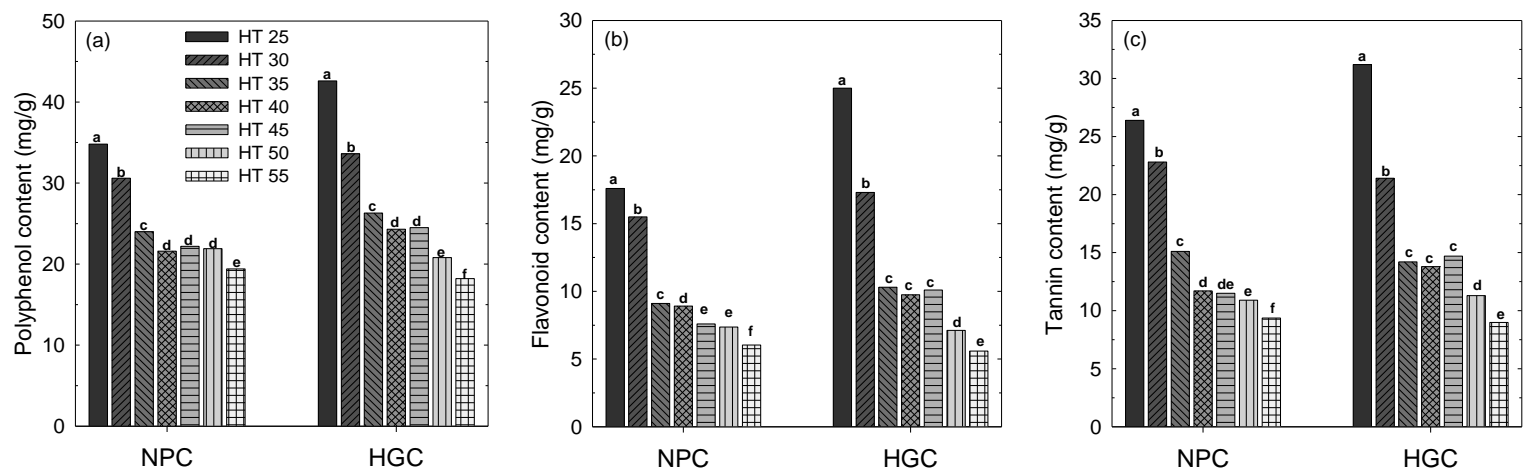

Fig. 2 Changes of antioxidants according to each harvest time of sorghum; (a) polyphenolic content, (b) flavonoid content, (c) tannin content. Different superscripts in bar graphs indicate significant differences at $p<0.05$ by Duncan's multiple range test.

small differences in thousand-grain weight (21.6$22.2 \mathrm{mg} / \mathrm{g}$ ) among HT 40, 45, and 50. The content of average polyphenol in HGC maintained a higher value of $2.3 \mathrm{mg} / \mathrm{g}$ or more than that of NPC. HGC presented differences in the polyphenol content of $24.4 \mathrm{mg} / \mathrm{g}$ between the earliest harvest time (HT 25) and the latest harvest time (HT 55). This change of HGC was $5 \mathrm{mg} / \mathrm{g}$ higher than that of NPC.

Flavonoid compounds mainly include anthocyanidins, flavonols, flavones, cathechins, and flavanones. A specific flavonoid compound has been known to exhibit various physiological activities including antioxidant and antibiotic depending on the structure $^{28}$. Flavonoids showed the highest amount at HT 25 as 17.6 and $25.0 \mathrm{mg} / \mathrm{g}$ in NPC and HGC, respectively (Fig. 2b).

Tannin, which has a close correlation with taste, flavour, and colour of tea, inhibits microbial growth and enzymatic activity ${ }^{29,30}$. Tannin was also decreased by the elapsed harvest time. The content at an early harvest time of HT 25 was 26.4 and $31.2 \mathrm{mg} / \mathrm{g}$ in NPC and HGC, respectively. The amounts correspond to a 2.8 and 3.5 folds higher than those at the latest harvest time of HT 55 for NPC and HGC, respectively (Fig. 2c).

The contents of total polyphenol, flavonoid, and tannin in an ethanol extract of sorghum are $6.23-7.51,1.76-2.25$, and $3.71-4.34 \mathrm{mg} / \mathrm{g}$, respectively ${ }^{31}$. The previous study showed higher values than those of current study. It is assumed that these differences are owing to the extracted solvents, year of production, or grown environment. In addition, our results show that the content of antioxidant components varies clearly depending on harvest time of sorghum. Hence we suggest that sorghum harvest time be determined depending on the purpose of sorghum application.

\section{Antioxidant activity}

Bioactive substances present an antioxidant activity by inhibition of major substances in foods such as fat via donating electrons to active radicals. Bioactive substances are thought to inhibit ageing via scavenging of active radicals in body ${ }^{32}$. Action of radical scavenging plays a critical role to prevent body from diseases and ageing ${ }^{28}$.

ABTS radical scavenging activity of sorghum at each harvest time showed the highest values at HT 25 for both NPC (90.8 mg/g TE) and HGC (113.8 mg/g TE) (Fig. 3). The activity clearly decreased depending on the elapsed harvest time, which was presented by 45.4 and $38.4 \mathrm{mg} / \mathrm{g}$ TE for NPC and HGC at HT 55, respectively. DPPH radical scavenging activity also showed the highest values at an earliest harvest time of HT 25 for both NPC ( $40.5 \mathrm{mg} / \mathrm{g}$ TE) and HGC (54.9 mg/g TE).

Antioxidant activity depends on harvest time due to the high correlations between phenolic compounds and ABTS or DPPH radical scavenging activity $^{33}$. As shown in foxtail millet and proso millet $^{33}$, it was expected that the antioxidant components and their activities maintain higher values at long cultivation periods of the later harvest time. However, in this study, since a high activity was observed at an early harvest time, a more detailed study is required to determine whether the antioxidant components and their activities result from differences in composition or from differential content ratio due to weight gain. Otherwise, the bran layer of sorghum exhibits higher activities for ABTS radical $(66.4 \mathrm{mg} / \mathrm{g}$ TE) and DPPH radical $(35.6 \mathrm{mg} / \mathrm{g}$ $\mathrm{TE})^{34}$. Since these results are very important for the 
Table 3 Correlations between antioxidants, antioxidation, cultivar and harvest time of sorghum seed.

\begin{tabular}{|c|c|c|c|c|c|c|}
\hline & Polyphenol & Flavonoid & Tannin & ABTS & DPPH & Cultivar \\
\hline Flavonoid & $0.990^{* * *}$ & & & & & \\
\hline Tannin & $0.976^{* * *}$ & $0.977^{* *}$ & & & & \\
\hline ABTS & $0.988^{* * *}$ & $0.982^{* *}$ & $0.974^{* *}$ & & & \\
\hline DPPH & $0.983^{* * *}$ & $0.978^{* *}$ & $0.964^{* *}$ & $0.993^{* * *}$ & & \\
\hline Cultivar & $0.167^{\mathrm{ns}}$ & $0.197^{\mathrm{ns}}$ & $0.084^{\mathrm{ns}}$ & $0.124^{\mathrm{ns}}$ & $0.140^{\mathrm{ns}}$ & \\
\hline $\mathrm{HT}$ & $-0.865^{* *}$ & $-0.843^{* *}$ & $-0.872^{* *}$ & $-0.884^{* * *}$ & $-0.888^{* *}$ & 0.000 \\
\hline
\end{tabular}

ns $=$ no significance; $* *=$ significance at $p<0.01$.
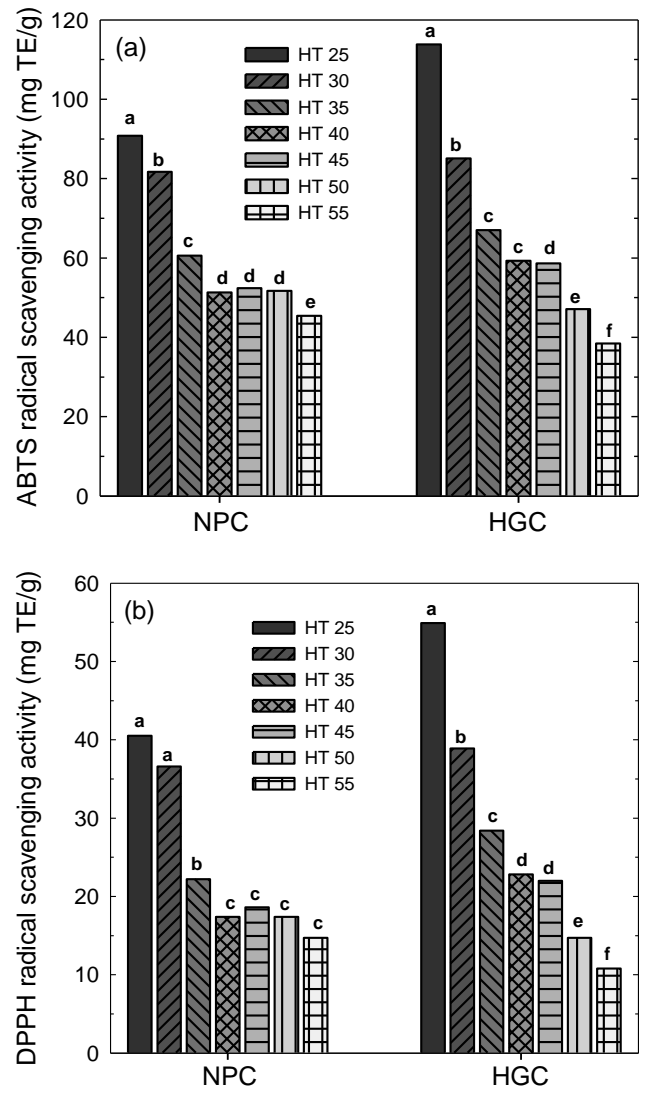

Fig. 3 Changes of antioxidant activities according to each harvest time of sorghum; (a) ABTS radical scavenging activity, (b) DPPH radical scavenging activity. Different superscripts in bar graphs indicate significant differences at $p<0.05$ by Duncan's multiple range test.

utilization of sorghum, we suggest that more studies of the bioactive substances of sorghum should be carried out in the future.

The components of antioxidant showed significantly positive correlations among them such as polyphenol, flavonoids, and tannin (Table 3). ABTS or DPPH radical scavenging activity showed also a significant correlation with the antioxidant compo- nents. In addition, ABTS radical scavenging activity exhibited a significant correlation with the DPPH radical scavenging activity. However, cultivar types showed no significant correlation with antioxidant components, antioxidation, or harvest time. In addition, harvest time showed significantly negative correlation with antioxidant components or antioxidation. We therefore suggest that sorghum with excellent antioxidant power should be applied as a good material for the production of functional foods at a suitable harvest time.

\section{CONCLUSIONS}

In this study, we examined general characteristics as well as representative antioxidant components and their activities of sorghum seeds at various harvest times. The morphological properties and chemical compositions showed various properties depending on the harvest time. Total polyphenols, flavonoids, and tannin contents, which are representative antioxidant components of the sorghum seeds, were in inversely proportional to harvest time. The earlier harvest time showed more ABTS and DPPH radical scavenging activities. These results reveal a high correlation between antioxidant components and ABTS or DPPH radical scavenging activities. Harvest time showed high negative correlations with antioxidant components or their activities. We therefore suggest that during the cultivation and production process of sorghum, it is critically important to select the cultivar depending on the purpose of application.

Acknowledgements: This work was supported by Priority Research Centres Programme through the National Research Foundation of Korea (NRF) funded by the Ministry of Education (2009-0093813).

\section{REFERENCES}

1. Ministry for Food, Agriculture, Forestry and Fisheries (2010) Statistical Yearbook, MIFAFF, Government of South Korea. 
2. Khosla R, Persaud N, Powell NL, Brann DE (1995) Water use of sorghum on a marginal soil in eastern Virginia. In: Agronomy Abstracts, American Society of Agronomy, Madison, WI, p 433.

3. Wiedenfeld B, Matocha J (2010) Planting date, row configuration and plant population effect on growth and yield of dryland sorghum in subtropical South Texas. Arch Agron Soil Sci 56, 39-47.

4. Deng B, Tammeorg P, Luukkanen O, Helenius J, Starr M (2017) Effects of Acacia seyal and biochar on soil properties and sorghum yield in agroforestry systems is South Sudan. Agroforest Syst 91, 137-48.

5. Wu G, Johnson SK, Bornman JF, Bennett SJ, Fang Z (2017) Changes in whole grain polyphenols and antioxidant activity of six sorghum genotypes under different irrigation treatments. Food Chem 214, 199-207.

6. Yoon ST, Jeong IH, Han TK, Kim YJ, Yu JB, Yang J, Ye MH, Baek SW, Kim KW (2016) Evaluation of crop characteristics of sorghum (Sorghum bicolor L.) germplasm for selection of excellent resources. Kor $J$ Plant Resour 29, 479-94.

7. Ritchie LE, Taddeo SS, Weeks BR, Carroll RJ, Dykes L, Rooney LW, Turner ND (2017) Impact of novel sorghum bran diets on DSS-induced colitis. Nutrients 9, E330.

8. Mosovska S, Mikulasova M, Brindzova L, Valik L, Mikusova L (2010) Genotoxic and antimutagenic activities of extracts from pseudocereals in the Salmonella mutagenicity assay. Food Chem Toxicol 48, 1483-7.

9. Thin T, Myat L, Ryu GH (2016) The effects of $\mathrm{CO}_{2}$ injection and barrel temperatures on the physiochemical and antioxidant properties of extruded cereals. Prev Nutr Food Sci 21, 271-80.

10. Uchimiya M, Ni X, Wang ML (2016) Structurereactivity relationships between the fluorescent chromophores and antioxidant activity of grain and sweet sorghum seeds. Food Sci Nutr 4, 811-7.

11. Kil HY, Seong ES, Ghimire BK, Chung IM, Kwon SS, Goh EJ, Heo K, Kim MJ, Lim JD, Lee D, Yu CY (2009) Antioxidant and antimicrobial activities of crude sorghum extract. Food Chem 155, 1234-9.

12. Awika JM, Rooney LW, Waniska RD (2005) Anthocyanins from black sorghum and their antioxidant properties. Food Chem 90, 293-301.

13. Dykes L, Rooney LW (2006) Sorghum and millet phenols and antioxidants. $J$ Cereal Sci 44, 236-51.

14. de Oliveira KG, Queiroz VAV, Carlos LA, Cardoso LM, Ava HMP, Anunciacao PC, Menezes CB, Silva EC, Barros F (2017) Effect of the storage time and temperature on phenolic compounds of sorghum grain and flour. Food Chem 216, 390-8.

15. Ramirez MB, Ferrari MD, Lareo C (2016) Fuel ethanol production from commercial grain sorghum cultivars with different tannin content. J Cereal Sci 69, 125-31.
16. Association of Official Analytical Chemists (2000) Official Methods of Analysis, 16th edn, AOAC, Washington, DC.

17. Dewanto V, Xianzhong W, Liu RH (2002) Processed sweet corn has higher antioxidant activity. J Agr Food Chem 50, 4959-64.

18. Duval B, Shetty K (2001) The stimulation of phenolics and antioxidant activity in pea (Pisum sativam) elicited by genetically transformed anise root extract. J Food Biochem 25, 361-77.

19. Brand-Williams W, Cuvelier ME, Berset C (1995) Use of a free radical method to evaluate antioxidant activity. LWT Food Sci Tech 28, 25-30.

20. Re R, Pellegrin V, Proteggente AR, Pannala A, Yang M, Catherine RE (1999) Antioxidant activities applying an approved ABTS radical caution decolorization assay. Free Radic Biol Med 26, 1231-7.

21. Lee SH, Hwang IG, Kim HY, Lee HK, Lee SH, Woo SH, Lee JS, Jeong HS (2010) Physicochemical property and antioxidant activity of Daehak waxy corns with different harvest time. $J$ Kor Soc Food Sci Nutr 39, 719-24.

22. Galindo A, Calín-Sánchez A, Collado-González J, Ondoño S, Hernández F, Torrecillas A, CarbonellBarrachina AA (2014) Phytochemical and quality attributes of pomegranate fruits for juice consumption as affected by ripening stage and deficit irrigation. J Sci Food Agr 94, 2259-65.

23. Kohyama N, Ono H, Yanagisawa T (2008) Changes in anthocyanins in the grains of purple waxy hullless barley during seed maturation and after harvest. J Agr Food Chem 56, 5770-4.

24. Lee HK, Hwang IG, Kim HY, Woo KS, Lee SH, Woo SH, Lee JS, Jeong HS (2010) Physicochemical characteristic and antioxidant activities of cereals and legumes in Korea. $J$ Kor Soc Food Sci Nutr 39, 1399-404.

25. Rice-Evans CA, Miller NJ, Paganga G (1997) Antioxidant properties of phenolic compounds. Trends Plant Sci 2, 152-9.

26. Cebeci F, Sahin-Yesilcubuk N (2014) The matrix effect of blueberry, oat meal and milk on polyphenols, antioxidant activity and potential bioavailability. Int J Food Sci Nutr 65, 69-78.

27. Cervellati R, Renzulli C, Guerra MC, Speroni E (2002) Evaluation of antioxidant activity of some natural polyphenolic compounds using the BriggsRauscher reaction method. J Agr Food Chem 50, 7504-9.

28. Hounsome N, Hounsome B, Tomos D, Edwards-Jones $G$ (2008) Plant metabolites and nutritional quality of vegetables. J Food Sci 73, R48-65.

29. Nakagawa T, Yokozawa T, Terasawa K, Shu S, Juneja LR (2002) Protective activity of green tea against free radical- and glucose-mediated protein damage. $J$ Agr Food Chem 50, 2418-22.

30. Kraus TEC, Yu Z, Preston CM, Dahlgren RA, Zasoski RJ (2003) Linking chemical reactivity and protein 
precipitation to structural characteristics of foliar tannins. J Chem Ecol 29, 703-30.

31. Woo KS, Ko JY, Seo MC, Song SB, Oh BG, Lee JS, Kang JR, Nam MH (2009) Physicochemical characteristics of the tofu (soybean curd) added sorghum (Sorghum bicolor L. Moench) power. J Kor Soc Food Sci Nutr 38, 1746-52.

32. Riaz M, Zia-Ul-Haq M, Saad B (2016) Anthocyanins and Human Health: Biomolecular and Therapeutic Aspects, Springer, Switzerland.

33. Woo KS, Lee JS, Ko JY, Song SB, Seo HI, Seo MC, Oh BG, Kwak DY, Nam MH, Oh IS, Jeong HS (2012) Antioxidant compounds and antioxidant activities of different varieties of foxtail millet and proso millet according to cultivation time. J Kor Soc Food Sci Nutr 41, 302-9.

34. Woo KS, Seo MC, Kang JR, Ko JY, Song SB, Lee JS, Oh BG, Park GD, Lee YH, Nam MH, Jeong HS (2010) Antioxidant compounds and antioxidant activities of the methanolic extracts from milling fractions of sorghum (Sorghum bicolor L. Moench). J Kor Soc Food Sci Nutr 39, 1695-9. 